ELORE (ISSN 1456-3010), vol. $14-2 / 2007$.

Julkaisija: Suomen Kansantietouden Tutkijain Seura ry.

[http://www.elore.fi/arkisto/2_07/jus2_07.pdf]

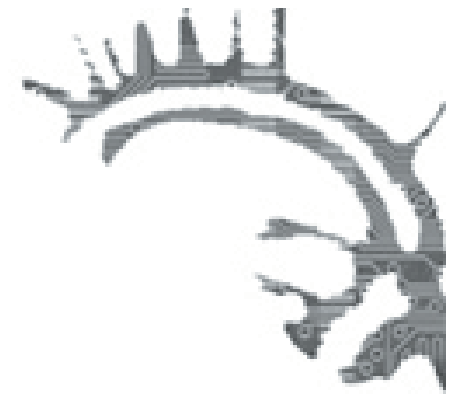

\title{
DANCE NARRATION AND THE FEMININE MIMESIS IN OB-UGRIAN WOMEN'S DANCES
}

\author{
$\underline{\text { Inka Juslin }}$
}

During the period 1996-1997, I interviewed two Mansi and two Khanty women about their dancing. My interest was kindled after I had seen them performing with the Ob-Ugrian bear ritual theatre group in Helsinki. The performance took place in October 1996 at the Teatro stage in Yrjönkatu. I was watching their performance in the audience, and I later watched scenes from the dances and miniature plays on a video recording of the performance (Asplund 1996). In this article, I focus on these Ob-Ugrian Khanty and Mansi women's dances, which have traditionally been performed in village rituals. Today active members of the community, such as artists, teachers and shamans, have revitalized these dances and other rite fragments, also performing them on theatre stages and in cultural centres (Pentikäinen 1998; Siikala \& Uljasev 2002). Although the performance space of the Siberian bear ritual tradition has changed over time, the context of the dances remains that of the tradition.

Three of my interviewees, a Khanty woman (born in 1968) and Mansi sisters (born in 1969 and 1971) represent the young generation. As a child, the young Khanty woman had attended some festivities related to the killing of the bear. Her father was a hunter and her aunt showed her women's dancing. As a student living in the capital of the Siberian Khanty-Mansiisk, she was more attracted to disco dancing, like other youngsters in Russia. The bear lore became more important to her later when she was herself doing ethnography in local villages. I also interviewed her together with the Mansi sisters, who had learned most of their dancing from their mother, an active dance teacher in the local communities. As children, the Mansi sisters had not been dancing in bear festivals, but they learned to perform rite fragments together with their mother. In the 1990s, they had performed on various theatrical stages in Russia and abroad.

The older generation Khanty woman (born in 1936) participated in village feasts as a child. In an interview, she told me that during the Soviet years it was not always easy to enhance local traditions. Being herself a schoolteacher, she had become active in revitalizing and teaching the dances and bear lore to children. To her, the idea 


\section{Dance Narration and the Feminine Mimesis}

of the locality of the dances and of the culturally specific nature of the movements was very important. She emphasised that the Ob-Ugrians have their own movement vocabulary, as well as rules about how to dance and how to perform the movements. (Khanty woman, born in 1936/interview 21.10.1996.)

I studied at the Department of Finno-Ugrian Studies of the University of Helsinki at the same time as the elder Mansi sister and the younger Khanty woman. We frequently met casually, so I did not always intentionally tape-record all our exchanges. I recorded some of our discussions, in which I had with me a language expert specialised in either Russian and/or Khanty and Mansi languages. When the women showed me special dances, I notated them with a choreological system, noting dance movements, movement qualities and dynamics. The choreological notation system is based on Rudolf Laban's movement analysis. Valerie Preston-Dunlop at the Laban Centre in London has developed the notation to be more convenient to use (Hodgson \& Preston-Dunlop 1990, 56; Preston-Dunlop 1992). I studied this system at the Laban Centre at the beginning of the 1990s as a dance student. The notation is done so that the observer uses her own body, making the movements herself and then relating the experiments to the notation. This article does not contain these elements, but my notation will be found in part in my master's thesis, completed in the Department of Finnish and Cultural Research of the University of Joensuu (Välipakka [Juslin] 2000).

In this article, I elaborate on two notions, that of the dance narration and the concept of feminine mimesis in the Khanty and Mansi women's dances. Dance narration refers to the interpretative surface of the dances, to the local notion of personal rbyth $m$, which the women discuss in relation to their dancing. It also denotes the lore of the dances narrated by the dance songs accompanying the bear feast. I pay attention to dance movements and to dance speech. Moreover, some dance songs are documented in the anthology The Great Bear (Honko \& Timonen \& Branch 1993), which I shall consider in relation to local conceptions of dancing. The personal rhythm and dance experience acquire meaning in relation to the poems narrating the femininity of the dances.

The dance lore not only points to the context of the bear dance event, but with various attributes illustrates how the women are dancing, how and in what kind of qualities they are moving their bodies in dancing. These narrative elements of dancing form a feminine mimesis of the bear feast. I understand that the feminine mimesis evolves together with the dances, as women perform their own gender. Traditionally, the Ob-Ugrians taught the dances only at the bear feast, where youngsters learned from elders - girls from women and boys from men. Women's dance movements are slightly different from men's in their aesthetics, and particularly in the manner of performing. Women perform in a lighter manner: with light and exact turns, with pauses and rhythmic stamping. These are tied together in the soft expressive movements of the hands and the upper body (Zornickaja 1981, 129-130). Feminine mimesis connects to the dance movements which narrating women's life, emphasising the everyday tasks and the sacredness of Nature. My interviewees showed me dance movements, constantly telling me how the dances narrate about these elements 
INKA JUSLIN

(Khanty woman, born in 1968/interview 24.10.1996). The feminine mimesis is a space, in which different aspects of life, the upbringing of youngsters, mothers' role in performance and respect for Nature come together.

\section{TEATRO PERFORMANCE AND OLD VILLAGE MILIEU}

The first references mentioning Ob-Ugrian Khanty and Mansi bear dances, go back 150-200 years in history (Hallowell 1926; Zornickaja 1981). The old sources mention that women and children danced with men at the bear feast, but they omit all other information including how people performed the movements, and also the styles of the dances. From the sociocultural point of view, at the time of the Hungarian ethnographer Gondatti (19th century) the Russification of the Ob-Ugrians was already apparent. This meant that people with 'know-how' of bear lore were sometimes hard to find. When Gondatti came to local Siberian settlements people had to go far to find an old man, who had the proper songs and details about the ceremony: "for without these the festivities would be of no account" (Hallowell 1926, 92).

The tradition of the Ob-Ugrian bear ritual is documented well in various ethnographical descriptions starting from the late $19^{\text {th }}$ century. The Finnish Artturi Kannisto and K. F. Karjalainen accomplished important field studies, which include details of bear events (Kannisto 1937; Karjalainen 1918). At the turn of the 20th century, Artturi Kannisto travelled in Mansi (formerly Vogul) Siberian Sosva-river regions paying special attention to the traditional songs, miniature plays and dances (Kannisto 1937). K. F. Karjalainen also accomplished his fieldwork at the turn of the $20^{\text {th }}$ century. He examined the traditional belief system of the North-Western Khanty people (formerly Ostyaks), also analysing the bear ritual context (Karjalainen 1918).

After the Russian Revolution, the position of Mansi women became more liberal, but it is noteworthy that women's roles always differed between regions (Bartens 1986,14). I discussed this with my interviewees. According to them, the position of married women in the past was quite radical in the sense that on marriage women became members of their new families to the extent that if a woman wished to go back to her mother people thought she would soon die (Khanty-woman, born in 1968/interview 24.11.1996). Then, in everyday life women used shawls to mark their marital status. A woman revealed her face to close relatives, at the same time hiding her cheeks and eyes from strangers and other men (Mansi-women, born in 1969 and 1971/interview 24.11.1996). These habits have changed over time.

The frameworks of the old ethnographic studies include a great enthusiasm and deep folkloric interest in the nuances of the bear ritual, giving a voice to oral history and epic songs, describing people's histories. However, what is lacking is the discussion behind the 'mystery' of a woman's shawl dancing in the bear feast. Old ethnographic descriptions repeat the same view, the male ethnographer's curious observation, where he looks at a woman's dancing recording how her entire upper body is covered. According to them, the women's participation in the ritual is very brief 


\section{Dance Narration and the Feminine Mimesis}

and ambivalent. A woman covers her naked skin while dancing, because it is a threat to the bear, which is the guest of honour at the feast house (Kannisto 1937, 8).

Kannisto's description of the village feast gives me hints about the past event. Through it, I can image the performers and audiences of the olden days. This gives me a better understanding of the Teatro performance which took place in October 1996 in Helsinki. The performance consisted of two active audiences, one being those of us sitting in our theatre seats, and the Khanty and Mansi 'audience' sitting on the stage. It seemed as if each performer was following a fellow actor and dancer to perform in his or her own time. Women were encouraging men in their dancing and visa versa. This indigenous audience responded to performers in action, women laughing at men's caricature scenes during miniature plays and so on. I can imagine how the Ob-Ugrian performers display a casual performance manner in their village setting. As a theatrical performance, there is room for improvisation and spontaneity. In Teatro, the Khanty and Mansi actors also touched their theatre audience, us, as we sat there. Some members came offstage for a while to make a collection.

After the Teatro performance was over, I also joined the party, eating the food and drinking vodka that during the performance had been placed on a table, on which the dead bear's skin was laid (a skin, head, and a pulley). People offered the bear food and vodka and there was a small fire burning on the table. In the performance sequence, between each small scene actors bowed to the bear kissing its nose before and after their performances. The Teatro performance also revealed that before each performative act people made some movements and gestures to cleanse the performance space and the performers' actions.

In the olden days, the village bear feast lasted for several days. Performances usually took place in the evenings, and throughout the whole occasion there were moments for each gender: some parts of the festivities were only carried out in single-sex groups. Kannisto states that women are not present when men perform 'sacred songs' among themselves, and women and children eat separately from men (Kannisto 1937, 12). Nevertheless, this nature of the 'sacredness' of the songs sometimes makes me doubt the meaning and the content of the words. When men drink among themselves at the festival, at times consuming large amounts of vodka, they might speak and sing content which they simply deem inappropriate for the ears of women and children. Younger Khanty woman told me that she had interviewed an old Khanty man, who mentioned her about men's sexual talk during the feast. When she asked a man what kinds of songs they sang, the man said, "well you know, but I cannot say it to a young woman" (Khanty-woman, born in 1968/interview 24.10.1996).

Male ethnographers have repeatedly addressed the large shawl which women use in their bear feast dancing. They argue that the act of covering women's bodies is connected to local taboos concerning woman's skin. The covering is a tangible marker of woman's sexual power, and to me it reveals something about the attraction of her sex. When a woman is dancing, this becomes even more apparent. For the men of the community, women's naked skin surface can be a surface for negotiating about their own male sexuality, also marking the time and space where and when they are not allowed to touch a woman or supposedly touch women who are 'off limits'. 
INKA JUSLIN

Rituals such as the Ob-Ugrian bear festival do not causally portray the values of the everyday life. They do not mirror the gender system of the socio-cultural life, but merely represent performances which also confirm the solidarity within the samesex group. In so doing they strengthen people's sexual identities (Schlegel 1990, 26). The display of femininity attached to Khanty and Mansi women's use of the shawl sometimes becomes apparent in the men's performance. At the Ob-Ugrian bear feast, the men have occasionally dressed up as women. They walk with feminine gestures using falsetto as a feminine voice etc. This cross-dressing is a compliment to women's sexuality, but it also draws outlines of men's masculine identities. Cross-dressing makes the shawl a feminine marker, because it presents the women, thus also connecting to the ritual's feminine centre. When men perform women's roles, they cover their faces and/or upper bodies with a shawl. At other times, they usually use masks in the miniature plays. These are made of bark with a large nose at the centre. The masks represent different identities, characters and ethnic groups (Khanty-woman, born in 1968/interview 24.10.1996). Some of the male performers carry a large wooden penis in the performance costume (Karjalainen 1918, 524-525).

When the shawl as a feminine symbol connects to men's dressing up as women it performs the movement of covering revealing. In assuming women's roles, men reveal their own gender and its content, including their own masculine sexuality, to become visible to other members of the community. They at the same time reversely bide their masculine sexuality when using women's clothes. Taboo negotiations about a woman's sexuality, in the old ethnographies connected to her naked skin, acquire new meaning when seen as part of this performance mobility. The naked skin seen as being a threat to the bear, who is the honoured guest, excessively performs the intense time of the carnival event, in which the aesthetic sphere differs from that of everyday life.

\section{Polysemic ethnomimesis}

For Aristotle, mimesis embodied artistic representation with the idea that art imitates life. Susan Kozel challenges the term to assign plural meanings in dance. Because the symbols are constantly shifting with lived experiences, mimesis should rather criticize any attempts to formalize the symbols (Kozel 1997, 101-108). On the level of interpretation of human actions, performances and dances, there is a need for criticism of the pure aesthetic functioning of artistic heritage, and likewise of the implications in which mimesis replicates the original. In fact, a hermeneutic concept of mimesis culminates in changing our understanding of the social and the aesthetic.

Post-Aristotelian theory of mimesis when conceptualized as part of critical hermeneutics, does not consider our human reality to be reducible to any kind of identical or mimetic process of reproduction of the past. The past is rather in a constant processes of exchange of socially and aesthetically performed multi-realities. Peoples' agency and active revival of cultural heritage tests the hierarchies of originality (Warnke 1987, 56-64). The Ob-Ugrian bear feast revitalization is remembering 


\section{Dance Narration and the Feminine Mimesis}

the past dances, also narrated in dance poems. Yet something new is manifest when women talk about their personal rhythm in dancing.

Today the Ob-Ugrian dance tradition of different families and kinship groups comes to performing and learning the dances (Khanty woman, born in 1936/interview 21.10.1996). Dance narration in the dance songs and in women's gendered performing with the shawl - the feminine mimesis of the bear feast - is not apart from this wholeness. It is the heritage which makes the discussion of mimesis important. The ethnomimesis of old village events on theatre stages means active remembering. Each bear performance has within itself previous performances; in the village events, the singers carved their performed songs in the wooden sticks.

The rite fragments carry information about the bear ritual heritage and about women's participation and role in it. Dancing today conveys information about the heritage. It counts for more than if a researcher were to concentrate on the principles and abstractions of the past. I understand that ethnomimesis is the 'locality' of the Ob-Ugrian dance language as its vocabulary is handled today. The dance movements have more than one meaning. This is also true of the polysemy of spoken languages (Ricoeur 1981a, 44).

Hence, what can a mimetic narrative offer to the phenomenology of individual time experience, to people now? In his existential analysis of time (adopted from Heidegger), Paul Ricoeur suggests that the making-present cannot be separated "from awaiting and retaining" (Ricoeur 1981b, 168-169). The nonlinear narrative of mimesis fills existential now with preoccupation of the may come. People direct their actions toward the future.

The hermeneutic and phenomenological understanding of mimesis signifies people's lived present; creation is part of agency. In Paul Ricoeur's phenomenology of reading mimesis brings together the lived (the phenomenological, experienced) and cosmological time (redefined Heideggerian accounts of time experience) (Ricoeur 1988). When I apply his narrative theory of three-fold mimesis to the bear feast, mimesis I of the mimetic trinity corresponds to prefigured time, recounting the bear lore and bear's ancestry with the Ob-Ugrian people. To interpret the present requires a stage in which representations and significances meet (Ricoeur 1988). The prefigured time relates to knowledge of the past. The theatrical performances act out village occasions. The past and its conventions are corporeal knowledge not separate from the present moment, where the meaning enacts new ways of composing creatively.

In Ricoeur's mimetic trinity, mimesis II stands for the metaphorical 'as if.' In the bear feast narrative, this means acting out the employment (see Knuuttila 1992, 155-158). Single actions do not play a major role, but the way they build sequences as narrative and as emplotments is significant. Whilst mimesis I concerns "scattered" representations, the second stage brings out the characters of the action, the performers. The second stage corresponds to the knowledge of making dances now from the Ob-Ugrian dance corpus.

Finally, in the three-fold mimesis comes a third stage, mimesis III, that relates to re-configuration. Here the audiences meet the space of the performers, who act as mediators between past and present. The 'archaic theatre' of Ob-Ugrians 
INKA JUSLIN

re-collects people's lives, making it theatre. Performative actions are about the ritual, because the reality is symbolically relevant to people in the now-moment. Theatrical performances and revitalization work in the local communities, in teaching the dances, nurture the sense of communality. The performers move between the past and present composing and creating something new out of the festival.

Revitalization makes sense in the hermeneutical timeframe of mimetic trinity. The experienced time functions together with narratives of the present. The actors create the plot so that it both utters and shapes their agencies. The first "mimetic relation refers in the case of an individual, to the semantics of desire". Here are incorporated the pre-narrative features, which bring together our basic human desires (Ricoeur 1988, 248). In the third mimetic stage, the actors may correspond to and correct the past phases. As the phases are lived there could be continuous possibilities for reinterpretations of the previous narratives, stories and performances, in which the latter can also change and correct the preceding: in which the ways out are poetic. The performance comes about in the active processes of re-signification of the actors (Ricoeur 1988, 248).

It is that the identities of Khanty and Mansi women dancers correspond to the world order of ethnomimetic narrative. Experiencing the bear lore and the bear epics which connect peoples' present to that of their ancestry, fulfills multiple desires. The lived experiences acquire their meaning within the framework of the heritage. Therefore, what has been historically narrated about the dancing, the materiality in the various accounts of the historical feast, which women are so well aware of, arrives in the present conferring significance on this moment's performing time. Various fragments, stories, and individual desires make today's bear lore. The world order corresponds to the time of between-ness wherein individuals dialectically collect the past and the creativity of the now-moment as "the interplay between being able to act and being bound to the world order" (Ricoeur 1981b, 173).

\section{THE BEAR EPICS AND FEMININE MIMESIS}

The bear festival has been a necessary occasion for teaching morality and ethics.

Parents taught their children how to behave and how not to behave.

For children participation was obligatory, they were learning with this folk pedagogy.

The parents were really teaching, not just by being role models. They were saying, do not do this, or else! Do not hurt an ant, because it is sacred.

(Khanty-woman, born in 1968/interview 24.10.1996.)

The bear ritual circumscribes an entire life sphere. In the festival, people play the everyday tasks so that they signify cultural representations assigned to each gender, and with pedagogical codes, with parody and mockery. As a pedagogical institution, the bear feast reproduces communal identity. The animal functions as a dividing symbol for the perceptual categories for the interior and exterior of the communal life. In the context of a feast, these categories overlap diversely (Anttonen 1996, 142). 


\section{Dance Narration and the Feminine Mimesis}

Some scholars put emphasis on the matriarchal and totemistic features of the Ob-Ugrian bear ritual. This approach reveals that both Khanty and Mansi people have long identified themselves as members of one of two moieties, the por moiety, that is more careful in upholding the rules of the (ancient) bear cult, and the mos' moiety, which adopted the bear feast customs much later. Moreover, the latter has adopted only certain features of the ancient cult, and especially those concerned with the entertaining parts of the festival (Honko 1993, 126).

Among the stories told at the old village festival was one of a bear giving birth to the first por woman. She was the one to become the primordial mother of the tribe. Lauri Honko suggests that the internationally widespread sharing of mixed marriages and metamorphosis themes (like the tale of the bear's son) calls for careful interpretation within the bear ritual context (Honko 1993, 126). Eva Schmidt assumes that in Ob-Ugrian culture the bear principle is one of the main areas of projection for the unconscious of human personality. The sexual relationship, that of a marriage between woman and bear (and in it a manifestation that the bear-husband and his human brothers-in-law are in a conflict) is not very important for the Ob-Ugrians (Schmidt 1989, 201). Merely in the Ob-Ugrian belief system, the bear to some extent became the organizing principle of the culture, standing for the portrayal of the affective lives of the people (Schmidt 1989, 189).

An anthology of Finno-Ugrian poetry The Great Bear contains examples of Khanty and Mansi bear lore, both epics songs and dance songs, which accompany the dances at bear feasts. Poem number 27: The Great Bear with the name of the anthology is an epical story, narrating the bear's relationship to humans; the animal speaks the story with its own mouth (Honko \& Timonen \& Branch 1993, 152-156). It was collected from the Khanty Irtysh region, and is associated with hunters who sing the poem as they carry a bear's dead body to their village. In the song's narration the dead bear itself is a singer, and its role is performed on its behalf by one of the hunting men's party. The poem begins with a description of the bear's origin in the sky. It is a daughter of the sky god (when usually it is a son). The poem narrates that at the beginning of time a bear was lowered down to earth in a cradle on the end of iron chains. The bear came upon the lands of humans, was killed by them and finally returned to its father by the same route as it had come (this myth is one of many narrating the origin of the bear, and common among the Ob-Ugrians, Lapps and Finns. See Honko \& Timonen \& Branch 1993).

I shall now highlight The Great Bear (Honko et al. 1993, 152-156) with verses with special references to women's bear feast dancing. A nature topos, a birch-covered island and a hill with slopes full of berries provide the setting of the poem. The place is the bear's own land, which the sky god has provided. In the scene, two men in searching the wood for bows appear on the island taking word back to their village about the rich harvest of berries. Hence, a group of women set out from the village to pick the berries. They have with them two children in their cradles, a boy and a girl. The women's action is interrupted dramatically by the approaching bear's roar, so they take quick flight but leave the children in their cradles to the mercy of the animal. In the following, the bear narrates how it encounters the two children. 
INKA JUSLIN

\author{
And I went \\ up \\ to the poor little girl half dead with fear: \\ "Poor little girl, you're dead, you're dead! \\ Your mother danced to honour me: \\ in a mean dress of cedar bark. \\ she danced for me \\ in birchbark apron like a foal \\ she danced for me." \\ And the poor little girl half dead with fear \\ I tossed into the hollow of my mouth \\ teeming with twenty teeth, and crunched her \\ bones \\ as though she were a duck. Then I went up \\ to the poor little boy half dead with fear: \\ "Poor little boy, you're dead, you're dead! \\ Your mother danced to honour me: \\ in clinking silver ornaments \\ she danced for me \\ in woollen skirt like squirrel skin \\ she danced for me \\ in beaded shoes like squirrel claws \\ she danced for me \\ in a blouse all adorned with birds \\ she danced for me. \\ in kerchief decked with forest birds \\ she danced for me." [...] (Honko et al. 1993, 154.)
}

The poem tells that the beast (a euphemism used instead of animal's name) kills the girl, as her mother had worn old and ragged clothes when she had danced at a festival in the bear's honour. The boy escapes death because his mother had worn her best clothes when dancing before the bear. According to Lauri Honko, the poem emphasizes the respect due to the bear and the norms of the bear ceremonies (Honko 1993, 122). This may be a reason, but it is not sufficient for understanding the idea of the feminine narratives of the festival.

Women's clothes, their outward appearances, seem at first glance to be the cause for the animal to choose its victim. As a norm 'due to the bear,' the poem repeats the narration of old time ethnographies, being in line with illustrations where woman's naked skin is a threat to the bear. The feminine mimesis illustrates and builds up the bear epics from a woman performer's point of view. When making woman's subject position visible, the notion criticizes the dominant ideas of nature and material culture, also creating the terms for representing itself. In women's ritual dancing, the feminine mimesis reconnects Nature and material life to women's experience. 


\section{Dance Narration and the Feminine Mimesis}

Women's experience is not a fixed or generalized category; this is true in any kind of phenomenological investigation, concerned with gender differences. Since ancient times, mothers have been associated with Nature and unthinking matter, lifeless and inessential matter. Feminine mimesis is a critical tool against such narratives (Irigaray 2000, 21-23; Whitford 1991, 58, 150). In the bear dance context the women's own narration and meaning making is crucial for real feminine content to emerge. When the utterances speak about the surface of women's skin or the use of the shawl they have to make it with more specific content.

One motive in The Great Bear is that the boy will one day become a hunter himself. The supposed hope is that he will adopt the techniques of a hunter knowing how to kill that dangerous beast, which at times threatens the human environment. The girl's future is more unknown; as we know, it is a common story around the world. To me the poem tells about the harshness of the Northern environment, where people have lived their nomadic lives in close relation to Nature. Child deaths are common in many places. It is a theme which also motivates a famous fairytale written by Hans Christian Andersen: 'The story of a Mother' (see Hastrup 1995, 63-65).

\section{KuURINKA's WISE DANCE}

It makes no sense to divide the Ob-Ugrian dances according to epic or lyrical ideas of narratives. Yet the dance songs are obviously related to dancing, accompanying the movements as music and creating space for thoughts about content of the dances. In the research literature, the feminine contents have been engaged with the poetic images of the dance songs. In addition, it may be noted that old-time ethnographies ascribed the role of epics to men's 'sacred songs.' However, dance songs in line with more general patterns of Khanty and Mansi oral poetry make effective use of poetic repetition. Raija Bartens identifies some typical parallels in their poetical lines. When a woman tells about her plaited hair, she uses multiple related attributes to enhance her appearance (Bartens 1986, 20). Poetic repetitions narrate what is feminine in the culture, in the vocabulary of poems and dance songs.

The dance songs carry special information about the dances, even describing the movements, as those of twisting and turning. The quality of how to perform the movements is also essentially part of their imagery. In the interviews, the Khanty and Mansi women took up the special relationship between songs and movements. People know many of the dances well as dance songs. For instance, Kunrinka Seemanowna at the Feast-House (poem 38 in The Great Bear) has many variants with similar kinds of poetic contents, which both Khanty and Mansi are familiar with. Kunrinka Seemanowna's dance does not include specific movements in order as in the choreography; the dance movements vary in different performance styles, which emphasize, for example, how to turn lightly in the dance.

Poem 38 in The Great Bear anthology is a dance: Kuurinka Seemanowna at the Feast-House. I. B. Kálmán collected it in 1957 from the Mansi regions. According to Kálmán, the singer who performed Kuurinka Seemanowna knew only the song. It was 
INKA JUSLIN

the dancer then making her movements to it (Honko 1993, 178-79). What the song represents for the collector is its way of using 'unusual' eulogies describing a girl's dancing style. The performer had emphasized that a dancing girl is honoured like the bear.

\author{
Little Kuurinka \\ dances and dances \\ and she can do it \\ honoured as a bear- \\ she is used to it. \\ This is a wise dance: \\ how she sways to it \\ how she can do it! \\ Into this feast-house \\ she bas lightly stepped \\ she has lightly come: \\ what a girl she is - \\ hands wise in wise dance \\ feet wise in wise dance \\ she dances, dances \\ her long-tasselled scarf \\ whirling and whirling \\ her bead-tipped sandals \\ tripping and tripping! (Honko et al. 1993, 178-179.)
}

In the poem the Kunrinka girl is a talented and experienced dancer, she is compared to the honoured bear. Her dance is a wise dance; she sways in her dancing and she has entered the feast-house with light steps.

The older Khanty woman performed me a variant of Kunrinka, which she called Katja's song (Khanty woman, born in 1936/interview 21.10.1996). The rhythmical beat is $4 / 4$, and the movements accompany the song one to one. Khanty and Mansi poetry is usually chanted and characteristically the poetic line does not follow the syllables of the words, the accent being on the musical beat. When the Khanty woman performs Katja's song both singing it and dancing it, she emphasizes the relationship between the dance movements and the melody. The melody narrates the personality of whom it portrays. The Khanty woman is a grandmother, who wishes to educate her granddaughter. The granddaughter, Katja, learns her dance and song as one whole. Together the movements and images of the song tell about maternal love: "look, this is my little girl, this is my little darling" (Khanty woman, born in 1936/interview 21.10.1996). She has created the movements for a child so they are simple enough for Katja to pick up and repeat with her own body. 
Katja learns the melody and movements as her grandmother teaches her the content, which tell about her personal character. She is like a squirrel, quick and wise in her movements. With her dance, she learns about Nature. All the elements: Nature, personal character, melody and movements are equally important in the process of learning (Khanty woman, born in 1936/interview 21.10.1996). Both Kuurinka Seemanowna and Katja's dance narrate about the ethnomimesis of the bear feast, they are examples of the creative process in which the dances connect to bear lore as a whole. In it, Nature as an environment of humans has a special role. Kuurinka's dance refers to the bear itself and Katja moves like a squirrel.

\section{The FeMALE BODY}

It should be noted that referring to only one idiom of culture lacks substance to portray the complete sphere of danced experiences (Saarikoski 2003). Dance, song, poetry and dance movements are an integral part of bear lore ethnomimesis, but the feminine mimesis needs further analysis.

Poem 36 in The Great Bear anthology called Women Women (Honko \& Timonen \& Branch 1993, 177) emphasized two movement patterns of the body, those of twisting and turning, and also addresses the performing qualities of good and clever. This repetitive pattern runs throughout the poem (here half of the poem is presented):

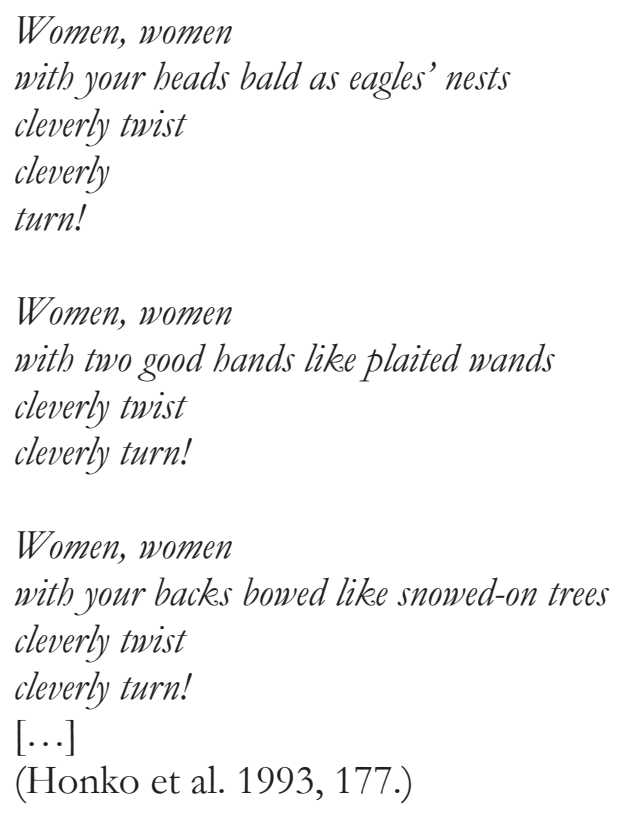

The feminine mimesis appears locally in pointing to the body parts: heads, hands, knees, feet, backs and even guts of the performers in action. Women Women evidently points to women's bodies, which are in the work and the bodies of mothers. The 
INKA JUSLIN

notions of wise, clever and good not only address a competent dancer, but also a good woman. The dancing hands also tell of the admired value of a woman's skillfulness in arts and crafts. The beautiful performance costume is part of this lineage of feminine accomplishment. As the Khanty and Mansi women keep telling, a specially skillful and good performer uses a small territory in her dancing and her moving body expresses softness (Khanty woman, born in 1968 and Mansi women, born in 1969 and 1971/interview 24.11.1996).

The dance songs highlight the feminine qualities of wisdom (poem Kuurinka) and cleverness and goodness (poem Women Women). My interviewees note this as a competence. The plasticity of bodies becomes visible in the dancer's use of space. An ideal performer takes only small steps and occupies less territory. This is apparent in Kuurinka, as she has lightly stepped and lightly come into the feast house.

As I observed in the video of the Teatro performance (Asplund 1996), the women performed light turns. They repeated turning many times first in one direction and then changed direction. Individual dancers varied turns and steps; each had her own hand movements. Each one repeated her movements on both sides of the body. The hand movements followed a certain pattern: the hands moving upwards on the plane of the head and after downwards reaching the space behind the lower back. Both this repeated light gesturing and light pressing of the hands, elbows bent or arms stretched seemed to be characteristic of the women's dances. The women's dancing created more curved than direct pathways in the space, and the use of the space was quite minimal in turnings and steps, hence occupying small territory.

Cultural dance competence is part of ethnomimesis. Different families and kinship groups have their own movements, and there is the knowhow of the degrees of movement. As an experienced dancer, the older Khanty woman discusses arm gestures, which are especially custom bound, people design their directions and levels (Khanty woman, born in 1936/interview 21.10.1996). The vocabulary of the dances, both for men and women, consists of movement patterns and sequences. However, the individual freedom which locals perceive as personal rhythm in dancing, is essential for women's aesthetic experience.

\section{THE PERSONAL RHYTHM}

There is social dancing, in which everybody who feels capable of dancing joins. Dancing is free, it is improvised, and each person chooses her movements and dances to the music. (Mansi woman, born in 1971/interview 24.11.1996.)

What appears important is the woman's personal input in the dancing. She chooses the movements which she wants to perform.

Some create new movements. Youngsters learn from those who have more competence. Then they refine the movements. A girl who masters the movements repeats exactly 


\section{Dance Narration and the Feminine Mimesis}

what she sees. If three girls adopt the same movements, one will perform them more slowly and other more quickly. The way one performs expresses her personality the character of a dancer. The movements are the same, but rbythm varies. (Mansi woman, born in 1969/interview 24.11.1996.)

The customs shape choreographic designs, which also connect to the matrilineal heritage of the women. The individual dancers either perform single movements that are part of these vocabularies or take choreographed movements and vary them in tempo. The idea of personal rbyth $m$ comes from a woman adopting designed choreography and making it her own with her rhythmical variation. The personal rhythm at its best defines the aesthetic experience of the feminine performance.

It also brings out the everyday life and the personal narratives attached to it. The traditional way of life is in the names of the dances, as in Fisherwoman's dance and Dance of a bird-cherry picking woman (Khanty woman, born in 1968/interview 24.10.1996). At the bear feast, dancing women have been acting out their lives; the names mimetically tell about the way of life, which is close to Nature. The dance movements do not mimic daily tasks and routines literally, but decode the experience attached to them.

When the hands are up, it means I am picking the berries... me like this [showing movements]. At the bear festival, one, for example, performs berry picking. Alternatively, how people were moving from one place to another, as the men were showing with their movements in the performance. (Khanty woman, born in 1968/interview 24.10.1996.)

Personal rhythm is a mimetic process for an individual dancer to connect her own gestures and movements to those of the cultural movements, to make them her own. People establish the dance movements as oral history, but the present moment opens up space for individual creativity. There is a choice in the order of movements, meaning that an individual may decide what kinds of movements she wishes to dance according to what movements fit and go along with her body and her rhythm. The women discuss spontaneity. Kunrinka Seemanowna's dance is a good example of the personal space in which young girl dances. Kuurinka sways to her dance with the quality of wisdom.

This is a wise dance:

how she sways to it

how she can do it! (Honko et al. 1993, 178.)

As young Kunrinka dances, she is not dancing alone. A singer compares her to the bear, thus her dancing narrates about her honoured and invisible partner. In respect, a woman's naked skin should not threaten the bear, quite contrary to old ethnographical descriptions (Kannisto 1937, 8). If there were a threat, it would be a male audience, 
INKA JUSLIN

who does not share the relationship of the young girl and the bear. Nonetheless, the male-dominance of the bear festival - and the old ethnographic narrations - had a symbolic power of othering the reproductive female gender and with it the dangerous animal which threatens the borders of human material life (see Anttonen 1996). Male audiences have witnessed scenes where women dance with their invisible partner.

\section{KNOWLEDGE OF THE INVISIBLE DANCE}

The Khanty and Mansi women discussed the large shawl in relation to matrilineal sacredness of dancing. A large shawl signifies an adult woman's body. When a woman uses it on a special occasion either at the bear feast or other festivities at which the family is present, the dancing is ritualistic. The shawl covers woman's upper body, head, chest, upper back and arms.

The Mansi sisters performed me a dance which they had inherited from their mother. Vera's dance was handed down from their grandmother, Vera: the dance is again one signifier of the feminine heritage. It goes into 2/4 time and the melody and the dance movements together create a polyrhythmic texture. The rhythmic complexity articulates an adult woman's life-experiences. Dance songs belonging to young girls are simpler in rhythm. In Vera's dance, the woman's clothing is also different from a young girl's costume. The large shawl marks an adult woman, whereas the long-tasselled scarf of Kuurinka, as well as Katja's plaited hair (as the Khanty woman expresses it to me) indicate the carelessness, which young girls still have.

The shawl indicates that a movement of women's covering at the bear festival is connected to the sacred animal. Both of the head of an animal, and the dancing women are covered (Kannisto 1937, 13). Kuurinka dances like the bear, which represents the ritual's feminine centre. The woman's covering completes the essence of the feminine sacred nature of the ritual. Moreover, a woman's competence to be a mother embodies the same sacred nature. The shawl as a feminine symbol surrounds and touches the woman's body, her naked skin and the surface of the upper and the lower back, head, hair, neck, shoulders and arms. It marks a woman's sexual difference, as it covers the sensitive and erotic areas of the female body. Nevertheless, in so doing it accentuates them. The gender of the dancer manifests not only the poetry of the dance songs, but also shapes the dancing itself, which is activity with several feminine signifiers. The dancing woman becomes a central figure in the feast house. It seems that her appearance is expected. She is not only the last person - coming even after the children - in the performance order of the feast (Kannisto 1937, 8-12), but as a mother, she becomes the very first.

Capturing the femininity as a part of the ethnomimesis of the festival requires noticing all the details in the natural topos, which people hold sacred in the indigenous Ob-Ugrian imagery. It is the negative movement of not touching and not pointing, which translate the otherness of the smallest things to signify the most important, the sacred. 


\title{
Dance Narration and the Feminine Mimesis
}

\begin{abstract}
Do not burt an ant, because it is sacred. The spider is also sacred and you are not allowed to touch it. If you kill it, you will pee on your bed. - And do not point a finger at the moon, or your finger gets ill! (Khanty woman, born in 1968/interview 24.10.1996.)
\end{abstract}

The spider is a metaphor for a mother. The best known Western artistic treatment of this theme is that of the French-born American sculptor Louise Bourgeois's giant female spiders: of which the huge Maman became famous when exhibited in the Tate Modern in London. Female spiders are able to protect, spin, weave and nurture. Ants are able to build nests. $A$ moon has been an attribute for the feminine in mythologies. The woman's interior is always a part of night (Irigaray 2000, 34). When a woman's interior connects her to night it is that her interior grows the secret of life.

The femininity also reserves and covers itself. The shawl connects women to sacred motherhood. It covers women's body parts and skin. A mother sets her shawl in motion with her dancing. As she moves covered, a baby moves inside her body covered. The feminine mimesis is there in the dancing mother, she being the most powerful sign in the sacred bear lineage. Western scholarship also emphasizes that a woman's waist in dancing is the most powerful part of her body; the solar plexus stands for support and for feminine power (Preston-Dunlop 1992, 23). The mother is like a spider; many times her work is invisible. When she dances, her body is covered. When she is pregnant, her skin covers the silent life. The moon bears the same analogy in various myths, representing the feminine, the night. In this analogy, one cannot point at the moon and cannot hurt the mother.

\section{ConClusions AND CHANGES}

The difference between ritual and theatrical performance is not always clear. Scholars have diverse opinions regarding what rituals cover and what are theatrical performances. Richard Schechner includes ritual in activities which relate to theatre: others are play, games, sports, dance and music. Studying rituals as more original or more primitive, and excluding them from Western theatrical forms would be misleading in terms of looking at the history of theatre, and that as an approach would also be ethnocentric (Schechner 2003, 7). Theatre and ritual are close relatives. As ritual accomplishes entertaining parts, theatre may also use efficacy as a medium in speaking to its audiences. The binary: efficacy/ritual, entertainment/theatre comes to the performance in which an active event is in a continuous process of transformation. The multiple polar tendencies are present in all performances, unexpected shifts of modes, styles, rhythms and perspectives leading to changes taking place. Moreover, the anti-structures keep breaking the performance structures, hence creating liminal spaces between performers and their audiences, and so on (Schechner 2003, 130).

The current role of the fragments is to carry messages from the past and to connect these to changes visible in the ecological reality. In Siberia, a renaissance 
INKA JUSLIN

of shamanism is one part of the ethnic revivals of resistance. This as a sign language could even be the last act for cultural survival (Pentikäinen 1998, 152). Rituals are changing in the contemporary world, but they encode new cultural and ethnic significances which relate to indigenous identity politics. The bear feast setting in its theatrical forms represents an act of survival.

While studying Ob-Ugrian dances in context, I have paid attention to the past to be able to understand the present. Reading the bear feast ethnomimesis has to be multimodal. My analysis of dance poems already shows that poetic images have the power to express the corporeality of dances.

The ethnomimesis encompasses the life sphere, human lifecycle and lineage in their entirety. In the now-moment of performances, one has a resistive power to create something new out of it. The older Khanty woman performed a song expressing her role as a contemporary artist, who draws on old poetry for her affects. She adopts the old hunting setting as her source of artistic inspiration. Her use of past tonus highlights that some of the old indigenous practices, hunting and reindeer herding are under threat because of the environmental disasters and effects of pollution in Siberia. Her song expresses resistance, showing that the mental topos has not disappeared from people's minds. It is as alive as people's dancing; it lives in poems, images and in spoken languages. Although times have changed, the meanings of the dances go far back in time (Khanty woman, born in 1936/interview 21.10.1996). Ultimately, her song narrates a story of a small hunter-fisherman, whose actions she contrasts with Nature. If this relationship is broken violently the meaning of traditional arts will change the location.

\section{He is a bunter and fisherman, the greatest, because he lives close to Nature. He is an amazing small hunter and fisherman; the contrasts are the great wilderness and a small buman (Khanty woman, born in 1936/interview 21.10.1996.)}

Phenomenological and hermeneutical attempts to perform effectively and truthfully an act of interpretation do not concern only dance and other artistic means of communication. Overall, human corporeal knowledge is essentially metaphoric in character (Välipakka [Juslin] 2003, 30-33).

Critical hermeneutical and phenomenological approaches support the view that the process of meaning are connected to "the idea of a reciprocal interplay between implicit assumptions and the reflective presentation of another's meaning, and, contrastively, one's own interpretive premises" (Kögler 1996, 83). The assumption of language as essential is non-negotiable, since it tends to determine all kinds of experiences in our lives, including those of the body. However, if many of the bodily outcomes of experiences are othered, made different and unknown in our interpretation, our new challenge is to tap into another kind of meaning than the purely textual.

The local bear feast ethnomimesis accounts for ritual hierarchy, which plays out each gender in unique ways. The dancing, the movements, the shawl all play out women's feminine performing. Men using the shawl at times, in their performing, also momentarily touch the feminine sacred within their bodies - and especially a 


\section{Dance Narration and the Feminine Mimesis}

male shaman does, as Juha Pentikäinen illustrates in his study of an old male Khanty shaman (Pentikäinen 1998, 55).

It is interesting that the Finnish ethnographer Karjalainen already pondered women's bodies and menstruation taboos in Ob-Ugrian culture. Women's menstrual cycle and birth-giving defined essential communal borders, excluding women from particular areas in the community (including spaces for men's weapons) (Karjalainen 1918, 40-41). To him the women's position did not signify that they were inferior in relation to the men of the community. Women also acted as shamans, which to him strongly pointed to the significant role of female deities (Karjalainen 1918, 543-544).

As I begin to imagine together with the women's speech and the dances the Ob-Ugrian theatre witnesses snow, taiga, animals - bear, reindeer, horses, fish and all little creatures - and rivers and humans in accordance with it. In this archaic theatre, the performer's task is not to explain to the audience. The stories come about in fragments, which together side by side like a montage visualize everyday life, as well as the invisible sights connected to it. I believe that the dances are effective in preserving and carrying on the life cycle. Dances are like poetry. I imagine the dancing to be poetic.

The woman is inside her shawl, she is under it, covering herself with it, revealing herself with it. She keeps turning, turning, takes a turn with it, and steps, small steps with it. She keeps maturing in her turning, quick and slow motion between her back and her lower back and upper chest, hands up and down in her turning. More angles come then, with soft turning the cultural movements of harder, even sharper hands, emphasis on working hands, fisherwoman's hands, berry-picking hands, hands tired with work, hands putting a baby to sleep. Her palms dry from water, from cleaning fish, from polishing fur, red and blue from berries, her nails coloured from their juice. She is a spider, a woman-spider, a woman-mother, who lulls her baby to sleep, sings her baby a lullaby, a moon-circle, a year, a next berry season to come. And her hands, again her hands, they are her skin, her offering to the moon, she puts them on her baby, heals its crying with her hands. And to the feast-house she comes, steps lightly, taking small almost invisible steps, but the back and the hands are in motion, the invisible motion even stronger; when in a sudden moment she realizes a new baby inside her shawl, it moves, and now she is covering it with her shawl and she is revealing it with her blush, her heart beating with her dance, her blood circulating inside ber skin. 
INKA JUSLIN

\section{REFERENCES}

\section{Interviews}

Khanty woman, born in 1968:

- 24.10.1996 (recorded on tape, with Elina Rahimova).

- 24.11.1996 (recorded on tape, with Elina Rahimova).

Khanty woman, born in 1936:

- 21.10.1996 (recorded on tape, with Elina Rahimova).

Mansi woman, born in 1969:

- 24.11.1996 (recorded on tape, with Elina Rahimova).

Mansi woman, born in 1971:

- 24.11.1996 (recorded on tape, with Elina Rahimova).

The tapes are in the writer's possession.

\section{Theatre performance}

19.10.1996 Ob-Ugrian theatre group performance of rite fragments at TEATRO stage, Yrjönkatu, Helsinki. Event organized by the M.A. Castren Society, and recorded on video by Anneli Asplund: Hantien ja Mansien Tanssit. Helsinki: SKS ̈̈ K 731996.

\section{Video}

ASPLUND, ANNELI 1996: Hantien ja Mansien tanssit. Video, 90 min. SKS Ä-K 73.1996. Helsinki: Suomalaisen Kirjallisuuden Seura.

\section{Literature}

ANTTONEN, VEIKKO 1996: Ihmisen ja maan rajat. Pybä kulttuurisena kategoriana. Suomalaisen Kirjallisuuden Seuran Toimituksia 646. Helsinki: Suomalaisen Kirjallisuuden Seura.

BARTENS, RAIJA 1986 (ed.): Siivekekäille jumalille, jalallisille jumalille: mansien ja bantien runoutta. Suomalaisen Kirjallisuuden Seuran Toimituksia 435. Helsinki: Suomalaisen Kirjallisuuden Seura.

HALLOWELL, A. IRWING 1926: Bear Ceremonialism. - American Anthropologist 28: $1-175$.

HASTRUP, KIRSTEN 1995: A Passage to Anthropology. Between Experience and Theory. London: Routledge. 


\section{Dance Narration and the Feminine Mimesis}

HODGSON, JOHN \& PRESTON-DUNLOP VALERIE 1990: Rudolf Laban, an Introduction to bis Work and Influence. Plymouth: Northcote House.

HONKO, LAURI 1993: Hunting. - Honko, Lauri \& Timonen, Senni \& Branch, Michael (eds.), The Great Bear. A Thematic Anthology of Oral Poetry in the Finno-Ugrian Languages. Finnish Literature Society Editions 533. Helsinki: Finnish Literature Society.

HONKO, LAURI \& TIMONEN, SENNI \& BRANCH, MICHAEL (eds.), 1993: The Great Bear. A Thematic Anthology of Oral Poetry in the Finno-Ugrian Languages. Finnish Literature Society Editions 533. Helsinki: Finnish Literature Society.

IRIGARAY, LUCE 2000: To Be Two. London: The Athlone Press. [Essere Due, Bollati Boringhieri, 1994]

KANNISTO, ARTTURI 1937: Voguulien karhumenoista. - Suomalais-Ugrilaisen Seuran Aikakauskirja XLVIII, Helsinki 1936-37. Helsinki: Suomalais-Ugrilainen Seura.

KARJALAINEN, K. F. 1918: Jugralaisten Uskonto. Helsinki: WSOY.

KNUUT'TILA, SEPPO 1992: Kansanhuumorin mieli: kaskut maailmankuvan aineksena. Suomalaisen Kirjallisuuden Seuran Toimituksia 554. Helsinki: Suomalaisen Kirjallisuuden Seura.

KOZEL, SUSAN 1997: The Story is Told as a History of the Body. Strategies of Mimesis in the Work of Irigaray and Bausch. - Desmond, Jane (ed.), Meaning in Motion. New Cultural Studies in Dance. London: Duke University Press.

KÖGLER, HANS HERBERT 1996: The Power of Dialogue. Critical Hermeneutics after Gadamer and Foucault. Cambridge: The MIT Press.

PENTIKÄINEN, JUHA 1998: Samaanit. Pohjoisten kansojen elämäntaistelu. Helsinki: Etnika.

PRESTON-DUNLOP, VALERIE 1991: Dance is a language. Isn't it? London: Laban Centre.

RICOEUR, PAUL 1981a: Hermeneutics and the Human Sciences. Essays on Language, Action and Interpretation. Cambridge: Cambridge University Press.

- 1981b: Narrative Time. - Mitchell, W. J. T. (ed.), On Narrative. Chicago: University of Chicago Press.

- 1988: Time and Narrative, volume 3. Chicago: The University of Chicago Press.

SAARIKOSKI, HELENA (ed.) 2003: Tanssi, tanssi-kulttuureja, tulkintoja. Tietolipas 186. Helsinki: Suomalaisen Kirjallisuuden Seura.

SCHECHNER, RICHARD 2003: Performance Theory. London: Routledge. [1988]

SCHLEGEL, ALICE 1990: Gender Meanings. General and Specific. - Sanday Reeves, Peggy \& Gallagher Goodenough, Ruth (eds.), Beyond the Second Sex. New Directions in the Anthropology of Gender. Pennsylvania: University of Pennsylvania Press.

SCHMIDT, EVA 1989: Bear Cult and Mythology of the Northern Ob-Ugrians. - Hoppal, Mihaly \& Pentikäinen, Juha, Uralic Mythology and Folklore. Ethnologica Uralica 1. Budapest \& Helsinki: Suomalaisen Kirjallisuuden Seura.

SIIKALA, ANNA-LEENA \& ULJASEV, OLEG 2002: Henkien maisema. Pohjoishantien pyhät paikat ja niiden rituaalit. - Lehtinen, Ildikó (ed.), Siperia. Taigan ja tundran kansoja. Helsinki: Museovirasto. 
INKA JUSLIN

VÄLIPAKKA [JUSLIN], INKA 2000: 'Tanssi viisailla käsillä ja byvillä käsillä' - Obinugrilainen sukupuolijärjestelmä naisten tanssien valossa. Joensuu: Department of Finnish and Cultural Research [Unpublished MA thesis].

- 2003: Tanssien sanat. Representoiva koreografia, eletty keho ja naistanssi. Joensuun Yliopiston Humanistisia Julkaisuja 34. Joensuu: University of Joensuu Press.

WARNKE, GEORGIA 1987: Gadamer. Hermeneutics, Tradition and Reason. Stanford: Stanford University Press.

WHITFORD, MARGARET 1991: Luce Irigaray: Philosophy in the Feminine. London: Routledge.

ZORNICKAJA, I. E. 1981: Vergleichen des Studium der Traditionellen Tanzkunst der Ob-Ugrischen Völker. - Congressus Quintus Internationalis Fenno-Ugristarum pars VIII. Helsinki: Suomalaisen Kirjallisuuden Seura.

Inka Juslin (previously Välipakka), $\mathrm{PhD}$, is a dance researcher and dance artist, who is currently a visiting scholar at the Department of Performance Studies at New York University. 